\title{
As inéditas obras para guitarra de Juan José Mantecón e Jesús Bal y Gay, as dúas figuras musicais galegas da Generación del 27
}

\author{
Unknown Pieces for Classical Guitar by Juan José Mantecón and Jesús \\ Bal y Gay, Two Galician Musicians of the Generation of 27
}

\author{
Samuel Diz \\ Conservatorio Superior de Música de Sevilla \\ Universitat Pompeu Fabra \\ samueldiz@samueldiz.com
}

[recibido 31/10/2014, aceptado 27/01/2015]

\section{RESUMO}

Atardecer e Pastoral, dúas obras musicais inéditas para guitarra dos compositores galegos Juan José Mantecón (1895-1964) e Jesús Bal y Gay (1905-1993), dedicadas ao guitarrista Regino Sainz de la Maza (1896-1981), e recuperadas recentemente no proxecto Guitarra clásica galega, liderado polo músico e investigador Samuel Diz (Tui, 1986) xunto á editorial Ouvirmos.

PALABRAS CHAVE: Guitarra clásica, Jesús Bal y Gay, Juan José Mantecón, Generación del 27, Residencia de Estudiantes.

\section{RESUMEN}

Atardecer y Pastoral, dos obras musicales inéditas para guitarras de los compositores gallegos Juan José Mantecón (1895-1964) y Jesús Bal y Gay (1905-1993), dedicadas al guitarrista Regino Sainz de la Maza (1896-1981), y recuperadas recientemente en el proyecto Guitarra clásica gallega, liderado por el músico e investigador Samuel Diz (Tui, 1986) junto a la editorial Ouvirmos.

PALABRas Clave: Guitarra clásica, Jesús Bal y Gay, Juan José Mantecón, Generación del 27’, Residencia de Estudiantes.

\begin{abstract}
Atardecer and Pastoral are two unknown musical pieces for classical guitar by Galician composers Juan José Mantecón (1895-1964) and Jesús Bal y Gay (1905-1993), dedicated to guitarist Regino Sainz de la Maza (1896-1982), and recovered recently in the project Galician classical guitar by musician and researcher Samuel Diz (Tui, 1986) and the publisher Ouvirmos.

KEY WORDS: Classical guitar, Jesús Bal y Gay, Juan José Mantecón, Generación del 27, Residencia de Estudiantes.

Diz, S. (2015): “As inéditas obras para guitarra de Juan José Mantecón e Jesús Bal y Gay, as dúas figuras musicais galegas da Generación del 27”, Madrygal (Madr.), 18, Núm. Especial: 547-554.

SUMARIO: 1. Preludio. 2. Juan José Mantecón (Vigo, 1895 - Madrid, 1964). 3. Barcelona acolle a "Moderna Escuela Española”. 4. Danza del Atardecer, inédito manuscrito para guitarra de Juan José Mantecón. 5. Pastoral, a inédita e descoñecida obra para guitarra de Jesús Bal y Gay. 6. Jesús Bal y Gay (Lugo, 1905 - Madrid, 1993). 7. Coda. 8. Referencias bibliográficas.
\end{abstract}




\section{PRELUDIO}

Todo parecía cerrado a una nueva generación española de músicos; pero en reserva, como recibiendo un mandato hereditario inalienable, la nueva generación estaba próxima a su eclosión como tal generación compacta, formada en número suficiente, el 8 por casualidad.

Y los ocho músicos han comenzado a bullir ya en plena performancia, apretados en el tanque del doble círculo emergente: Salvador Bacarisse, Julián Bautista, Rosita García Ascot, Ernesto Halffter, Rodolfo Hallfter, Juan José Mantecón, Gustavo Pittaluga, Fernando Remacha.

Tenía que suceder, necesitaban hacerse partícipes del nuevo encargo, y ya en todos los programas tendrán que aparecer sus nombres para justificar la legitimad del tiempo, que sin ellos sería tiempo pocho y baldío. ¡Ya tenemos hermanos declarados en el otro arte!

A la manera franca española, están todos caracterizados por una clara utilización de todo lo moderno, y las nuevas imágenes ruedan en el piano, y suspiran en los aparatos de viento, y rasguean los instrumentos de cuerda con burlonería elevada a lo épico musical.

Entramos en una nochebuena de la música española, una nueva natividad en que se renuevan todos los símbolos de la música, fieles, por más que no quieran, a la primera zampoña. (Gómez de la Serna 1930)

Vinte e nove de novembro de 1930. A madrileña Residencia de Estudiantes acolle unha cita singular na historia. Un concertoconferencia no que os protagonistas son oito mozos compositores (de 24 a 35 anos) que procuran unha nova linguaxe artística a partir do ronsel que Manuel de Falla ${ }^{1}$ imprime nas súas personalidades, tomando o nome de "Moderna Escuela Española", e que a musicoloxía outorga posteriormente o nome de "Grupo de los Ocho". Entre os seus integrantes atopamos o inxustamente esquecido Juan José Mantecón.

\section{JUAN JOSÉ MANTECÓN (VIGO, 1895 - MADRID, 1964)}

De personalidade multidisciplinar, Juan José Mantecón nace en Vigo o 29 de xullo de 1895. Aos dez anos de idade trasládase coa súa familia a Madrid, cidade en que realiza estudos de Dereito, xunto a Filosofía e Letras, na

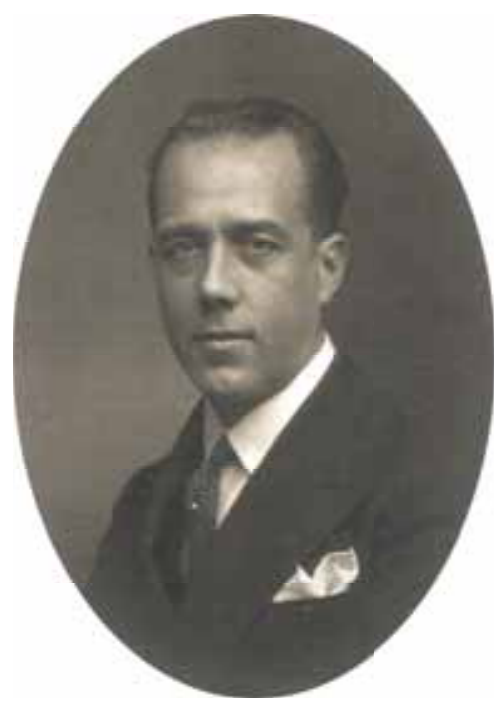

Universidade Complutense, incorporándose ao Ministerio de Facenda, no que permanece até a súa xubilación. A súa participación na vida musical española é moi activa desde a súa xuventude: encontramos os seus primeiros

${ }^{1}$ Baixo o letargo romántico que durante décadas se apoderou do repertorio da guitarra e os seus intérpretes, liderado polo intimismo de Francisco Tárrega e o seu discípulo, o guitarrista catalán Miquel Llobet, o encargado de estrear a Homenaje pour 'Le tombeau de Claude Debussy' de Manuel de Falla. Esta obra, publicada na revista parisina Le Revue Musicale en decembro de 1920, transforma o son do instrumento no símbolo modernista nacional que as artes plásticas demandan desde comezos de século. Nese continuo diálogo interdisciplinar, cómpre destacar o cadro El viejo guitarrista (1903) ou a escultura cubista Guitarra (1912) de Pablo Picasso, artista que curiosamente non coñece o compositor gaditano até uns meses antes da publicación da súa única obra para guitarra. Encontro reflectido na carta datada en abril de 1919 enviada a Sergei Diaghilev, creador e alma dos Ballets Rusos, quen prepara por aquel entón a estrea de El sombrero de tres picos: "Recuerdo muy bien el día -en el Palace [de Madrid]- en que hemos hablado Picasso y yo de tenerle con nosotros". 
escritos musicais na revista ovetense Ojanguren en 1912, e desde abril de 1914 realiza as funcións de secretario primeiro da sección de música no Ateneo de Madrid.

Políglota (dominio do inglés, francés, alemán, italiano e portugués), alén da composición musical, Juan José Mantecón dedicou a súa vida artística á pedagoxia, á estética e á crítica musical; foi pioneiro nas conversas radiofónicas a través dos micrófonos de Unión Radio e destacou pola súa intensa actividade no diario $L a$ Voz de 1920 a 1934 baixo o pseudónimo Juan del Brezo (Prieto Guijarro 2001).

En xullo de 1926 contrae matrimonio coa pianista Carmen María Ocón, unión sen descendencia. Tras a Guerra Civil, mantén o seu posto no Ministerio de Facenda, continuando o seu contacto coa música nas continuas clases particulares - de acordo coa súa arraigada vocación pedagóxica-, ofrecendo conferencias e publicando escritos, principalmente no periódico El Alcázar.
Juan José Mantecón falece en Madrid, na clínica da Concepción, o 24 de marzo de 1964, e sería enterrado no camposanto de San Isidro.

\section{BARCELONA ACOLLE A "MODER- NA ESCUELA ESPAÑOLA”}

Despois da presentación na Residencia de Estudiantes recollida no diario $\mathrm{El} \mathrm{Sol}$ por Ramón Gómez de la Serna, a Associació de Música "Da Camera" de Barcelona convida os "vuit joves mestres de la nova generació castellana" para interpretar as súas obras no emblemático Palau de la Música Catalana, nun concerto que ten lugar o mércores 11 de febreiro de 1931.

No programa de man, Juan José Mantecón -baixo o seu pseudónimo Juan del Brezo- asina o manifesto ${ }^{3}$ do grupo, como introdución estética á selección de oito partituras, entre as que atopamos Danza del Atardecer do propio Mantecón. A interpretación das obras conta co concurso da Orquestra Clásica e as pianistas

\footnotetext{
${ }^{2}$ Programa de man do concerto (11/02/1931).

3 "El vínculo común que liga a los ocho compositores que han recibido la merced de la atención de la "Associació de Música de Camera", es únicamente su amor al arte de los sonidos; la necesidad de dar forma lírica a sus emociones y conceptos. En puridad de verdad no puede decirse que la misma estética o la misma técnica conforme y anime sus producciones. Han preferido mantener incólume, en lo posible, la individualidad, con sus vicios y virtudes, que someterlas a la estricta regla de una especie de cenobio, que, si acaso diera al grupo más cohesión, restaría lo que es característico de la obra de arte: personalidad, autonomía, perfil propio. Pero como el perfil de las cosas vive en función del distorno del paisaje que lo rodea, es fatal que el producto de estos ocho músicos mantenga, aunque remota, una comunidad espiritual y de factura, que los aproxime, evitando entre ellos un manifiesto antagonismo o explícita enemistad. // Todos, quien más quien menos, son hijos del siglo, como se diría en la pasada fraseología romántica; es decir, que sus impulsos sentimentales y morales los mueve una actualidad, un presente que se traduce en las formas y procedimientos técnicos que postula la música moderna. Conviene advertir que sus intenciones y preferencias se inclinan, más que al estilo germánico actual, cuya cabeza visible es Schönberg, al que denominamos latino, entre el que, a pesar de su eslavismo, incluimos a Strawinsky [sic]; sin que se desdeñe, y en alguno de nosotros se cultive con voluntad manifiesta, el politonalismo, por otra parte, procedimiento que no es sólo privativo de la escuela de Schönberg. // El tiempo se encargará de definir quién de todos ellos tiene más razón. Los fueros de la amistad y convivencia nos impiden señalar quiénes de entre nosotros han recibido mayores mercedes y dones para lo menesteres líricos. Ustedes son los encargados de enjuiciar y otorgar el mejor galardón de los generosos plácemes. // Todos queremos hacer constar aquí que nuestro cordial interés es, sin duda, superior a nuestros merecimientos, y que el aliento que con él recibimos, serán razón para preservar en el camino emprendido, hasta llegar a una madurez, a una sazón digna de vuestra cortesía, sensibilidad y cultura. Entonces volveremos, ufanos, a ofrecéroslos. // Hemos de consignar también, que para evitar nuestra fatiga, y excesiva y dilatada extensión, y para acomodarnos a las exigencias del concierto, venimos, cada uno, con aquellas obras que por sus dimensiones y estructura puedan entrar, más pronto y fácilmente, en el área de nuestra amistad y contento. Con que sólo una parte de ella nos otorgárais, daríamosnos por satisfechos".
} 
Alicia Halffter e Rosita García Ascot, a que Mantecón presenta coas seguintes verbas:

Rosa García Ascot es para nosotros Rosita, y Rosita es la intérprete a la que confiamos con más gusto la interpretación de nuestras propias obras. Discípula de Falla y compositora de finos matices y técnica, es como la novia de la música. A ella lleva esa su grácil sonrisa y amistad, ese gesto que hace que todo en ella se transfigure en cordialidad. (Brezo 1931)

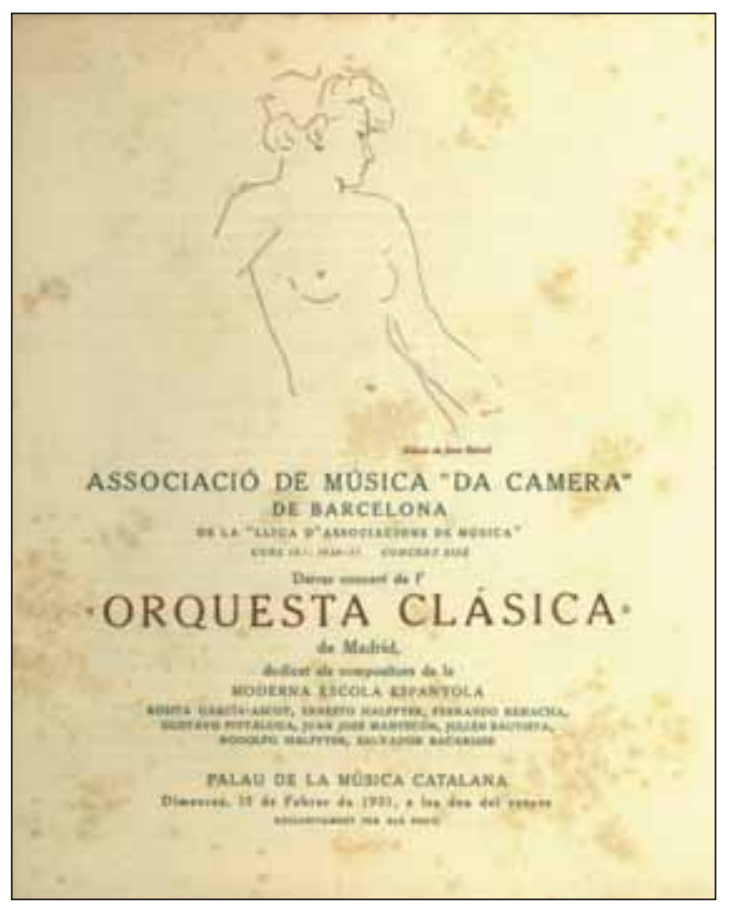

Ao día seguinte, La Vanguardia dedica un artigo á crónica do concerto con detalles de cada unha das obras, coa seguinte recensión da interpretación de Danza del Atardecer: "Oímos luego una evocadora y nostálgica «Danza del atardecer», muestra de la fácil y distinguida escritura de Juan José Mantecón, que ha aureolado de indiscutible autoridad el seudónimo de «Juan Buscón» [sic], con que firma sus sabrosas críticas musicales" ( $L a$ Vanguardia, 12/02/1931).

\section{DANZA DEL ATARDECER, INÉDITO MANUSCRITO PARA GUITARRA DE JUAN JOSÉ MANTECÓN}

En febreiro de 1930, Juan José Mantecón entrega o manuscrito para guitarra de Atardecer a Regino Sainz de la Maza, guitarrista burgalés que mantén unha importante relación con cada un dos integrantes do Grupo de los Ocho, despertando unha importante admiración polas súas extraordinarias dotes interpretativas: "Dueño de una técnica más sólida y mejor fraguada; de una técnica que trata de salir por los fueros legítimos de la guitarra, sin extravasar sus típicas posibilidades expresivas, buscando, más que su valor pintoresco, su sustancia lírica" (Brezo 1929). 